\title{
Terpenoid and carbonyl emissions from Norway spruce in Finland during the growing season
}

\author{
Hannele Hakola $^{1}$, Virpi Tarvainen ${ }^{1}$, Arnaud P. Praplan ${ }^{1}$, Kerneels Jaars ${ }^{2}$, Marja Hemmilä ${ }^{1}$, Markku Kulmala ${ }^{3}$, \\ Jaana Bäck ${ }^{4}$, and Heidi Hellén ${ }^{1}$ \\ ${ }^{1}$ Finnish Meteorological Institute, Atmospheric Composition Unit, P.O. Box 503, 00101 Helsinki, Finland \\ ${ }^{2}$ Unit for Environmental Sciences and Management, North-West University, Potchefstroom, South Africa \\ ${ }^{3}$ Department of Physics, P.O. Box 64, 00014 University of Helsinki, Helsinki, Finland \\ ${ }^{4}$ Department of Forest Ecology, P.O. Box 27, 00014 University of Helsinki, Helsinki, Finland
}

Correspondence to: Hannele Hakola (hannele.hakola@fmi.fi)

Received: 25 August 2016 - Discussion started: 11 October 2016

Revised: 14 February 2017 - Accepted: 15 February 2017 - Published: 8 March 2017

\begin{abstract}
We present spring and summer volatile organic compound (VOC) emission rate measurements from Norway spruce (Picea abies L. Karst) growing in a boreal forest in southern Finland. The measurements were conducted using in situ gas chromatograph with 1 to $2 \mathrm{~h}$ time resolution to reveal quantitative and qualitative short-term and seasonal variability of the emissions. The measurements cover altogether 14 weeks in years 2011, 2014 and 2015. Monoterpene (MT) and sesquiterpene (SQT) emission rates were measured all the time, but isoprene only in 2014 and 2015 and acetone and $\mathrm{C}_{4}-\mathrm{C}_{10}$ aldehydes only in 2015 . The emission rates of all the compounds were low in spring, but MT, acetone, and $\mathrm{C}_{4}-\mathrm{C}_{10}$ aldehyde emission rates increased as summer proceeded, reaching maximum emission rates in July. Late summer mean values (late July and August) were 29, 17, and $33 \mathrm{ng} g(\mathrm{dw})^{-1} \mathrm{~h}^{-1}$ for MTs, acetone, and aldehydes respectively. SQT emission rates increased during the summer and highest emissions were measured in late summer (late summer mean value $\left.84 \mathrm{ng} g(\mathrm{dw})^{-1} \mathrm{~h}^{-1}\right)$ concomitant with highest linalool emissions most likely due to stress effects. The between-tree variability of emission pattern was studied by measuring seven different trees during the same afternoon using adsorbent tubes. Especially the contributions of limonene, terpinolene, and camphene were found to vary between trees, whereas proportions of $\alpha$-pinene $(25 \pm 5 \%)$ and $\beta$-pinene $(7 \pm 3 \%)$ were more stable. Our results show that it is important to measure emissions at canopy level due to irregular emission pattern, but reliable SQT emission data can be measured only from enclosures. SQT emissions
\end{abstract}

contributed more than $90 \%$ of the ozone reactivity most of the time, and about $70 \%$ of the $\mathrm{OH}$ reactivity during late summer. The contribution of aldehydes to $\mathrm{OH}$ reactivity was comparable to that of MT during late summer, 10-30\% most of the time.

\section{Introduction}

The boreal forest is the largest terrestrial biome, forming an almost continuous belt around the Northern Hemisphere. The boreal forest zone is characterized by a short growing season and a limited number of tree species. The most common tree species are Scots pine, Norway spruce, and silver and downy birch and they produce and emit vast amounts of biogenic volatile organic compounds (VOCs) (Bourtsoukidis et al., 2014a, b; Bäck et al., 2012; Cojocariu et al., 2004; Grabmer et al., 2006; Hakola et al., 2001, 2006; Tarvainen et al., 2005; Yassaa et al., 2012). The compounds are mainly isoprene, monoterpenes (MTs), sesquiterpenes (SQTs), and oxygenated volatile organic compounds (OVOCs) (Tarvainen et al., 2007). There is a variety of factors controlling these emissions - both biotic (Pinto-Zevallos et al., 2013; Joutsensaari et al., 2015) and abiotic stress (Vickers et al., 2009; Bourtsoukidis et al., 2012, 2014c) factors can initiate or alter VOC emissions. Abiotic stress factors have been reviewed by Loreto and Schnizler (2010). Terpenes, for example, relieve oxidative and thermal stresses of trees. Many stress factors can also interact and cause addi- 
tive effects (Niinemets, 2010; Holopainen and Gershenzon, 2010). Biotic stresses such as acarid species infestation have been shown to initiate farnesene and linalool emissions in spruce seedlings (Kännaste et al., 2008). Emission potential and composition varies a lot between different tree species (Guenther et al., 2012). However, there is also a lot of variation in the emissions of different individuals of the same tree species. Bäck et al. (2012) showed that Scots pine trees of the same age, growing in the same environment, emit very different monoterpene selections. These so-called different chemotypes cause uncertainties in emission modelling.

In the atmosphere VOCs are oxidized, which affects the tropospheric ozone formation (Chameides et al., 1992) and contributes to the lifetime of methane by consuming hydroxyl radicals. In addition, reaction products of VOCs also participate in the formation and growth of new particles (Tunved et al., 2006). In smog chamber studies secondary organic aerosol (SOA) yields for different hydrocarbons and even for different MTs have been found to vary considerably (Griffin et al., 1999). Jaoui et al. (2013) studied SOA formation from SQT and found that the high reactivity of SQT produced generally high conversion into SOA products. Furthermore, they found that the yields were dependent on the oxidant used and were highest for nitrate radical $\left(\mathrm{NO}_{3}\right)$ reactions. Of the SQT acidic products, only $\beta$-caryophyllinic acid has been observed in ambient samples (Jaoui et al., 2013; Vestenius et al., 2014). Due to their high reactivity, SQT are not usually found in ambient air. Hakola et al. (2012) detected longifolene and isolongifolene in boreal forest air during late summer. Hence, the best way to evaluate the atmospheric impact of SQTs is to measure them from emissions.

In addition to isoprene and MTs and SQTs, plants also emit large amounts of oxygenated compounds - i.e. alcohols, carbonyl compounds, and organic acids (Koppmann and Wildt, 2007). OVOCs containing six carbon atoms $\left(\mathrm{C}_{6}\right)$ are emitted directly by plants often as a result of physical damage (Fall, 1999; Hakola et al., 2001). Saturated aldehydes (hexanal, heptanal, octanal, nonanal, and decanal) have also been found in direct emissions of plants (Wildt et al., 2003) as well as methanol, acetone, and acetaldehyde (Bourtsoukidis et al., 2014b).

In the present study we conducted online gaschromatographic measurements of emissions of MTs and SQTs as well as $\mathrm{C}_{4}-\mathrm{C}_{10}$ saturated aliphatic carbonyls from Norway spruce (Picea abies L. Karst) branches. Although Norway spruce is one of the main forest tree species in central and northern Europe, there are relatively limited amount of data on its emissions (Hakola et al., 2003; Grabmer et al., 2006; Bourtsoukidis et al., 2014a, b; Yassaa et al., 2012). Rinne et al. (2009) identified knowledge gaps concerning VOC emissions from the boreal environment and concluded that there is a lack of knowledge in nonterpenoid emissions from most of the boreal tree species. They also pointed out that chemotypic variations are not well enough understood to be taken into account in emission modelling. To fill this knowledge gap we conducted biogenic volatile organic compound (BVOC) emission measurements from Norway spruce. The online gas chromatograph mass spectrometer (GC-MS) was chosen because in addition to detection of individual MTs it allows sensitive detection of SQTs, which is often difficult to perform under field conditions. The online measurements were considered essential for evaluating the factors affecting emission rates, for example their temperature and light dependence. Our campaigns cover periods of years 2011, 2014, and 2015 during spring and summer, altogether about 14 weeks. In 2015 also carbonyl compounds were added to the measurement scheme, since there are no earlier data of their emissions.

\section{Methods}

\subsection{VOC measurements}

The measurements were conducted at the SMEAR II station (Station for Measuring Forest Ecosystem-Atmosphere Relations; $61^{\circ} 51^{\prime} \mathrm{N}, 24^{\circ} 18^{\prime} \mathrm{E}$; 181 a.s.l.) in Hyytiälä, southern Finland (Hari and Kulmala, 2005) in 2011, 2014, and 2015. The measurements took place in spring/early summer 2011 ( 2 weeks in April, 5 days in May and 3 days in June), spring/summer 2014 (1 week in May, 2 weeks in June and 1 week in July), and summer 2015 (1 week in June and 2 weeks in August) and they were conducted using an in situ gas chromatograph.

Two different trees were measured; tree 1 in 2011 and tree 2 in 2014 and 2015. The selected trees were growing in a managed mixed conifer forest (average tree age ca. 50 years), and located about $5 \mathrm{~m}$ from the measurement container. The height of tree 1 in 2011 was about $10 \mathrm{~m}$ (age about 40 years). The measured branch was a fully sunlit, healthy lower canopy branch pointing towards a small opening at about $2 \mathrm{~m}$ height. In 2014 and 2015 a younger tree (tree 2, ca. $1 \mathrm{~m}$ tall, age ca. 15 years) about $5 \mathrm{~m}$ away from the tree used in 2011 was selected for the study. The branches were placed in a Teflon enclosure and the emission rates were measured using a dynamic flow-through technique. The setup is shown in Fig. 1. The volume of the cylindrical transparent Teflon enclosure was approximately $8 \mathrm{~L}$ and it was equipped with inlet and outlet ports and a thermistor (Philips KTY 80/110, Royal Philips Electronics, Amsterdam, Netherlands) covered with Teflon tubing inside the enclosure. The photosynthetically active photon flux density (PPFD) was measured just above the enclosure by quantum sensor (LI-190SZ, LI-COR Biosciences, Lincoln, USA).

The flow through the enclosure was kept at about 3$5 \mathrm{~L} \mathrm{~min}^{-1}$. Ozone was removed from the incoming air using manganese oxide $\left(\mathrm{MnO}_{2}\right)$-coated copper nets. The emission rates were measured using the online GC-MS. From the enclosure outlet port air was directed through the $6 \mathrm{~m}$ long fluorinated ethylene propylene (FEP) inlet line (i.d. $1 / 8$ in.) to 


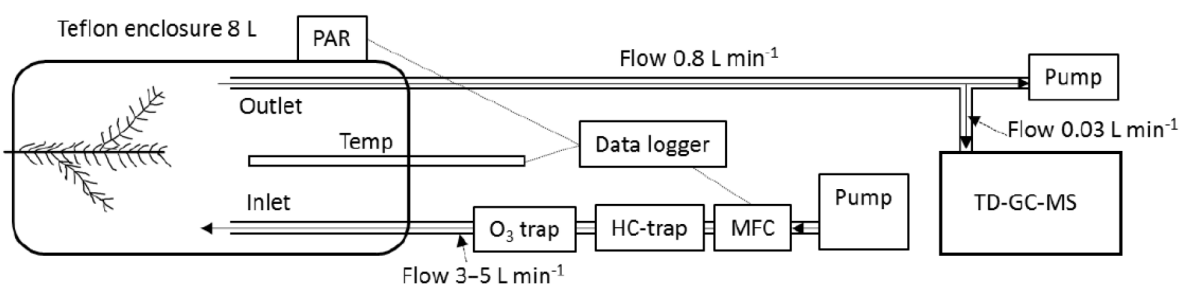

Figure 1. The emission measurement setup.

the GC-MS with a flow of $\sim 0.8 \mathrm{~L} \mathrm{~min}^{-1}$. Subsamples were taken from this main flow with a flow of $40-60 \mathrm{~mL} \mathrm{~min}^{-1} \mathrm{di}$ rectly into the cold trap of a thermal desorption unit (Perkin Elmer ATD-400) packed with Tenax TA in 2011 and Tenax TA/Carbopack-B in 2014 and 2015. The trap material was changed since isoprene was found not to be retained fully in the cold trap in 2011 . The trap was kept at $20^{\circ} \mathrm{C}$ during sampling to prevent water vapour present in the air from accumulating in the trap. The thermal desorption instrument was connected to a gas chromatograph (HP 5890) with DB-1 column $(60 \mathrm{~m}$, i.d. $0.25 \mathrm{~mm}$, f.t. $0.25 \mu \mathrm{m})$ and a mass selective detector (HP 5972). One 20 min sample was collected every other hour. The system was calibrated using liquid standards in methanol injected on Tenax TA-Carbopack B adsorbent tubes. The detection limit was below $1 \mathrm{pptv}$ for every MT and SQT.

The following compounds were included in the calibration solutions: 2-methyl-3-buten-2-ol (MBO) (Fluka), camphene (Aldrich), 3-carene (Aldrich), p-cymene (SigmaAldrich), 1,8-cineol (Aldrich), limonene (Fluka), linalool (Aldrich), myrcene (Aldrich), $\alpha$-pinene (Sigma-Aldrich), $\beta$-pinene (Fluka), terpinolene (Fluka), bornylacetate (Aldrich), longicyclene (Aldrich), isolongifolene (Aldrich), $\beta$-caryophyllene (Sigma), aromadendrene (Sigma-Aldrich), $\alpha$-humulene (Aldrich), $\beta$-farnesene (Chroma Dex). Isoprene was calibrated using gaseous standard from the National Physical Laboratory (NPL). We had no standard for sabinene and therefore it was quantified using the calibration curve of $\beta$-pinene, because both species elute close to each other and their mass spectra are similar. Therefore the results for sabinene are only semi-quantitative, but it enables the observations of diurnal and seasonal changes. Compared to offline adsorbent methods this in situ GC-MS had clearly lower background for carbonyl compounds and in 2015 we were able to measure also acetone/propanal and $\mathrm{C}_{4}-\mathrm{C}_{10}$ aldehyde emission rates. The aldehydes included in the calibration solutions were: butanal (Fluka), pentanal (Fluka), hexanal (Aldrich), heptanal (Aldrich), octanal (Aldrich), nonanal (Aldrich), and decanal (Fluka). Unfortunately, acetone co-eluted with propanal and the calibration was not linear due to high acetone background in adsorbent tubes used for calibrations.

\subsection{Calculation of emission rates}

The emission rate is determined as the mass of compound per needle dry weight and per time according to

$E=\frac{\left(C_{2}-C_{1}\right) F}{m}$.

Here $C_{2}$ is the concentration in the outgoing air, $C_{1}$ is the concentration in the incoming air, and $F$ is the flow rate into the enclosure. The dry weight of the biomass $(m)$ was determined by drying the needles and shoot from the enclosure at $75^{\circ} \mathrm{C}$ for $24 \mathrm{~h}$ after the last sampling date. We also measured needle leaf areas, and the specific leaf area (SLA) is $136 \mathrm{~m}^{2} \mathrm{~g}^{-1}$.

\subsection{Emission potentials}

A strong dependence of biogenic VOC emissions on temperature has been seen in all emission studies of isoprene, MTs, and SQTs (e.g. Kesselmeier and Staudt, 1999; Ciccioli et al., 1999; Hansen and Seufert 2003; Tarvainen et al., 2005; Hakola et al., 2006). The temperature-dependent pool emission rate is usually parameterized using a log-linear formulation:

$E(T)=E_{\mathrm{S}} \exp \left(\beta\left(T-T_{\mathrm{S}}\right)\right)$,

where $E(T)$ is the emission rate $\left(\mu \mathrm{gg}^{-1} \mathrm{~h}^{-1}\right)$ at leaf temperature $T$ and $\beta$ is the slope $\frac{\mathrm{d} \ln E}{\mathrm{~d} T}$ (Guenther et al., 1993). $E_{\mathrm{S}}$ is the emission rate at standard temperature $T_{\mathrm{S}}$ (usually set at $30^{\circ} \mathrm{C}$ ). The emission rate at standard temperature is also called the emission potential of the plant species, and while it is sometimes held to be a constant it may show variability related to, for example, season or the plant developmental stage (e.g. Hakola et al., 1998, 2001, 2003, 2006; Tarvainen et al., 2005; Aalto et al., 2014).

As well as the temperature-dependent nature of the biogenic emissions, light dependence was also discovered in early studies of plant emissions (see, e.g., the review of biogenic isoprene emission by Sanadze, 2004 and Ghirardo et al., 2010). The effect of light on emission potentials is based on the assumption that emissions follow a similar pattern of saturating light response to that which is observed for photosynthesis, and the formulation of the temperature effect is adopted from simulations of the temperature response of en- 
zymatic activity. The algorithm formulation is given, for example, in Guenther et al. (1993) and Guenther (1997).

In this work we have carried out nonlinear regression analysis with two fitted parameters, arriving at individual standard emission rates and slope values for the modelled MT, SQT and carbonyl compounds during each model period. The compounds analysed with the temperature-dependent pool emission rate were the most copiously emitted MTs and SQTs, other MTs, other SQTs, acetone, and sum of aldehydes. The light- and temperature-controlled instant emission rates were obtained for isoprene. An alternative modelling approach was tested using a hybrid emission algorithm, which has both the temperature-dependent pool emission and the light and temperature-controlled instant emission terms.

\subsection{Chemotype measurements}

In order to estimate the between-tree variability of the emissions, we conducted a study in 2014 , where we made qualitative monoterpene analysis from six different spruces (trees $3-$ 8) growing in the same area not farther than about $10 \mathrm{~m}$ from each other. All the trees were about $1 \mathrm{~m}$ high and naturally regenerated from local seeds. A branch was enclosed in a Teflon bag and after waiting for $5 \mathrm{~min}$ we collected a 5 min sample on a Tenax TA/Carbopack-B tube for analysis later in a laboratory using a Perkin-Elmer thermodesorption instrument (Turbomatrix 650) connected to a Perkin-Elmer gas chromatograph (Clarus 600) mass spectrometer (Clarus 600T) with DB-5 column. The samples were taken during one afternoon on 24 June 2014.

\subsection{Calculating the reactivity of the emissions}

We calculated the total reactivity of the emissions $\left(\mathrm{TCRE}_{x}\right)$ by combining the emission rates $\left(E_{i}\right)$ with reaction rate coefficients $\left(k_{i, x}\right)$ :

$\operatorname{TCRE}_{x}=\sum E_{i} k_{i, x}$.

This determines approximately the relative role of the compounds or compound classes in local $\mathrm{OH}$ and $\mathrm{O}_{3}$ chemistry. The reaction rate coefficients are listed in Table 1. When available, temperature-dependent rate coefficients have been used. When experimental data were not available, the reaction coefficients were estimated with the AopWin ${ }^{\mathrm{TM}}$ module of the $\mathrm{EPI}^{\mathrm{TM}}$ software suite (https://www.epa.gov/tsca-screening-tools/ epi-suitetm-estimation-program-interface, EPA, USA).

\section{Results and discussion}

\subsection{Weather patterns during the measurements}

According to the statistics of the Finnish Meteorological Institute, the weather conditions in Finland were close to nor- mal during the growing season in the years the measurements were carried out. The main features of the weather patterns are characterized here briefly to provide an average estimate of the conditions in the measurement years compared with the long-term average (the 30-year climatological normal period) conditions in Finland.

In 2011, the spring was early and warm. Thermal spring (mean daily temperature above $0^{\circ} \mathrm{C}$ ) started in the whole country during the first few days of April. The average temperatures in central Finland were $2-3^{\circ} \mathrm{C}$ higher than the normal long-term average temperatures. The precipitation in April was about $70 \%$ of the long-term average, and even a little less in central Finland.

The same pattern continued in May, with slightly higher temperatures than the normal long-term average. Towards the end of the month the weather turned more unstable, with more rains and cooler night temperatures. The average temperature in June was a little over $2{ }^{\circ} \mathrm{C}$ higher than the normal long-term average, and there were some intense thunderstorms.

In 2014, the weather conditions in May were quite typical, with the average temperatures close to the long-term average values in all parts of the country. The month started with temperatures cooler than the long-term average, and the cool period continued for about 3 weeks. After the cool period the weather became warmer with a southeastern air flow, and hot (over $25^{\circ} \mathrm{C}$ ) air temperatures were observed in southern and central parts of the country. Towards the end of May, cooler air spread over the country from the northeast, and the temperature drops could be high in eastern Finland. May was also characterized with precipitation, especially in eastern Finland. June started with a warm spell, but towards the end the weather was much cooler, with the average temperatures 1 to $2^{\circ} \mathrm{C}$ lower than the long-term average. The precipitation was regionally quite variable in June, the amount could be double the long-term average in some areas, while the amounts were only half of it in many places in central Finland. July was much warmer than long-term average temperature, especially in western Finland and in Lapland. July also had very little rain.

In 2015 , the June average temperatures were 1 to $2^{\circ} \mathrm{C}$ below the long-term averages, especially in the western parts of central Finland, and southern Lapland. There were also more rain showers than normally. In July the cold spell and rainy days continued, with average temperatures below the longterm averages, especially in the eastern parts of the country. Highest precipitation rates were measured in the southern and western coastal regions, and in the eastern parts of the country. In August the warmth returned after two cooler months, with average temperatures 1 to $2^{\circ} \mathrm{C}$ above the longterm average values. August also had very little rain, except for some parts in eastern Finland and in Lapland.

The observed mean temperature and precipitation amounts at the Juupajoki weather station in Hyytiälä during each mea- 
Table 1. $\mathrm{OH}$ and $\mathrm{O}_{3}$ reaction rate coefficients used in reactivity calculations.

\begin{tabular}{|c|c|c|c|c|}
\hline Species & $k_{\mathrm{OH}}\left(\mathrm{cm}^{3} \mathrm{~s}^{-1}\right)$ & Reference & $k_{\mathrm{O}_{3}}\left(\mathrm{~cm}^{3} \mathrm{~s}^{-1}\right)$ & Reference \\
\hline Isoprene & $2.7 \times 10^{-11} \cdot e^{390 / T}$ & Atkinson et al. (2006) ${ }^{\mathrm{a}}$ & $1.03 \times 10^{-14} e^{-1995 / T}$ & Atkinson et al. (2006) \\
\hline 2-Methyl-3-buten-2-ol & $6.3 \times 10^{-11}$ & Atkinson et al. (2006) $)^{\mathrm{a}}$ & $1.0 \times 10^{-17}$ & Atkinson et al. (2006) ${ }^{\mathrm{a}}$ \\
\hline$\alpha$-Pinene & $1.2 \times 10^{-11} \cdot e^{440 / T}$ & Atkinson et al. $(2006)^{\mathrm{a}}$ & $8.05 \times 10^{-16} \cdot e^{-640 / T}$ & IUPAC $^{b}$ \\
\hline Camphene & $5.33 \times 10^{-11}$ & Atkinson et al. (1990a) & $6.8 \times 10^{-19}$ & IUPAC $^{b}$ \\
\hline Sabinene & $1.17 \times 10^{-10}$ & Atkinson et al. (1990a) & $8.2 \times 10^{-17}$ & IUPAC $^{b}$ \\
\hline$\beta$-Pinene & $1.55 \times 10^{-11} \cdot e^{467 / T}$ & Atkinson and Arey (2003) & $1.35 \times 10^{-15} \cdot e^{-1270 / T}$ & IUPAC $^{b}$ \\
\hline Myrcene & $9.19 \times 10^{-12} \cdot e^{1071 / T}$ & Hites and Turner (2009) & $2.65 \times 10^{-15} \cdot e^{-520 / T}$ & IUPAC $^{b}$ \\
\hline 3-Carene & $8.8 \times 10^{-11}$ & Atkinson and Arey (2003) & $4.8 \times 10^{-17}$ & IUPAC $^{b}$ \\
\hline$p$-Cymene & $1.51 \times 10^{-11}$ & Corchnoy and Atkinson (1990) & $<5.0 \times 10^{-20}$ & Atkinson et al. (1990b) \\
\hline Limonene & $4.2 \times 10^{-11} \cdot e^{401 / T}$ & Gill and Hites (2002) & $2.8 \times 10^{-15} \cdot e^{-770 / T}$ & IUPAC $^{\mathrm{b}}$ \\
\hline 1,8-Cineol & $1.11 \times 10^{-11}$ & Corchnoy and Atkinson (1990) & $<1.5 \times 10^{-19}$ & Atkinson et al. (1990b) \\
\hline Linalool & $1.59 \times 10^{-10}$ & Atkinson et al. (1995) & $\geq 3.15 \cdot 10^{-16}$ & $\begin{array}{l}\text { Grosjean and } \\
\text { Grosjean (1998) }\end{array}$ \\
\hline Terpinolene & $2.25 \times 10^{-10}$ & Corchnoy and Atkinson (1990) ${ }^{\mathrm{a}}$ & $1.6 \times 10^{-15}$ & IUPAC \\
\hline Bornylacetate & $1.39 \times 10^{-11}$ & Coeur et al. (1998) & - & \\
\hline Longicyclene & $9.35 \times 10^{-12}$ & AopWin $^{\mathrm{TM}}$ v1.92 & - & \\
\hline Isolongifolene & $9.62 \times 10^{-11}$ & AopWin $^{\mathrm{TM}}$ v1.92 & $1.0 \times 10^{-17}$ & IUPAC $^{b}$ \\
\hline$\beta$-Caryophyllene & $2.0 \times 10^{-10}$ & Shu and Atkinson $(1995)^{\mathrm{a}}$ & $1.2 \times 10^{-14}$ & IUPAC $^{\mathrm{b}}$ \\
\hline$\beta$-Farnesene & $1.71 \times 10^{-10}$ & Kourtchev et al. (2012) & $1.5 \times 10^{-12} \cdot e^{-2350 / T}$ & IUPAC $^{b}$ \\
\hline$\alpha$-Humulene & $2.9 \times 10^{-10}$ & Shu and Atkinson $(1995)^{\mathrm{a}}$ & $1.2 \times 10^{-14}$ & IUPAC $^{b}$ \\
\hline Alloaromadendrene & $6.25 \times 10^{-11}$ & AopWin ${ }^{\mathrm{TM}} \mathrm{v} 1.92$ & $1.20 \times 10^{-17}$ & AopWin ${ }^{\mathrm{TM}}$ v1.91 \\
\hline Zingiberene & $2.87 \times 10^{-10}$ & AopWin ${ }^{\mathrm{TM}}$ v1.92 & $1.43 \times 10^{-15}$ & AopWin $^{\mathrm{TM}}$ v1.91 \\
\hline Acetone & $\begin{array}{l}8.8 \times 10^{-12} \cdot e^{-1320 / T} \\
+1.7 \times 10^{-14} \cdot e^{423 / T}\end{array}$ & Atkinson et al. (2006) ${ }^{\mathrm{a}}$ & - & \\
\hline Butanal & $6.0 \times 10^{-12} \cdot e^{410 / T}$ & Atkinson et al. (2006) ${ }^{\mathrm{a}}$ & - & \\
\hline Pentanal & $9.9 \times 10^{-12} \cdot e^{306 / T}$ & Thévenet et al. (2000) & - & \\
\hline Hexanal & $4.2 \times 10^{-12} \cdot e^{565 / T}$ & Jiménez et al. (2007) & - & \\
\hline Heptanal & $2.96 \times 10^{-11}$ & Albaladejo et al. (2002) & - & \\
\hline Octanal & $3.2 \times 10^{-11}$ & AopWin ${ }^{\mathrm{TM}}$ v1.92 & - & \\
\hline Nonanal & $3.6 \times 10^{-11}$ & Bowman et al. (2003) & - & \\
\hline Decanal & $3.5 \times 10^{-11}$ & AopWin ${ }^{\mathrm{TM}} \mathrm{v} 1.92$ & - & \\
\hline
\end{tabular}

${ }^{a}$ IUPAC recommendation. ${ }^{b}$ IUPAC Task Group on Atmospheric Chemical Kinetic Data Evaluation (http://iupac.pole-ether.fr).

Table 2. Mean temperatures $\left({ }^{\circ} \mathrm{C}\right)$ and rain amounts $(\mathrm{mm})$ during each measurement month in Hyytiälä.

\begin{tabular}{lrr|rr|rr}
\hline & \multicolumn{2}{c|}{2011} & \multicolumn{2}{c|}{2014} & \multicolumn{2}{c}{2015} \\
\cline { 2 - 7 } & temp & rain & temp & rain & temp & rain \\
\hline April & 4.5 & 17.4 & & & & \\
May & 9.3 & 44.3 & 9.4 & 57.4 & & \\
June & 15.8 & 65.3 & 11.8 & 94.8 & 11.9 & 81.5 \\
July & & & 18.6 & 44.1 & 14.6 & 86.7 \\
August & & & & & 15.2 & 12.6
\end{tabular}

surement month in 2011, 2014, and 2015 are shown in Table 2 .

\subsection{Variability of the VOC emissions}

Seasonal mean emission rates of isoprene, 2-methyl-3-buten2-ol (MBO), MTs, and SQTs are presented in Table 3 and
Fig. 2. Typical diurnal variations of the most abundant compounds for each season are shown in Fig. 3. Since most of the emission rates of the measured compounds were higher in late summer than in early summer, we calculated the spring (April and May), early summer (June to mid-July) and late summer (late July and August) mean emissions separately. This describes that the emission rate changes better than monthly means.

Isoprene emission rates were low in spring and early summer, but increased in August. In spring emission rates were below detection limit most of the time and early and late summer means were $1.3 \pm 3.7$ and $6.0 \pm 12 \mathrm{ng}$ (dry weight $)^{-1} h^{-1}$, respectively. The highest daily maxima isoprene emissions were about 70-80 $\mathrm{ng} g(\mathrm{dw})^{-1} \mathrm{~h}^{-1}$, but usually they remained below $20 \mathrm{ng} \mathrm{g}(\mathrm{dw})^{-1} \mathrm{~h}^{-1}$. Our measured values (Table 3) match very well with the measurements by Bourtsoukidis et al. (2014b) who report season medians varying from $1.6 \mathrm{ng}$ (dry weight $)^{-1} \mathrm{~h}^{-1}$ in autumn to $3.7 \mathrm{ng} g(\mathrm{dw})^{-1} \mathrm{~h}^{-1}$ in spring. However, while the highest 

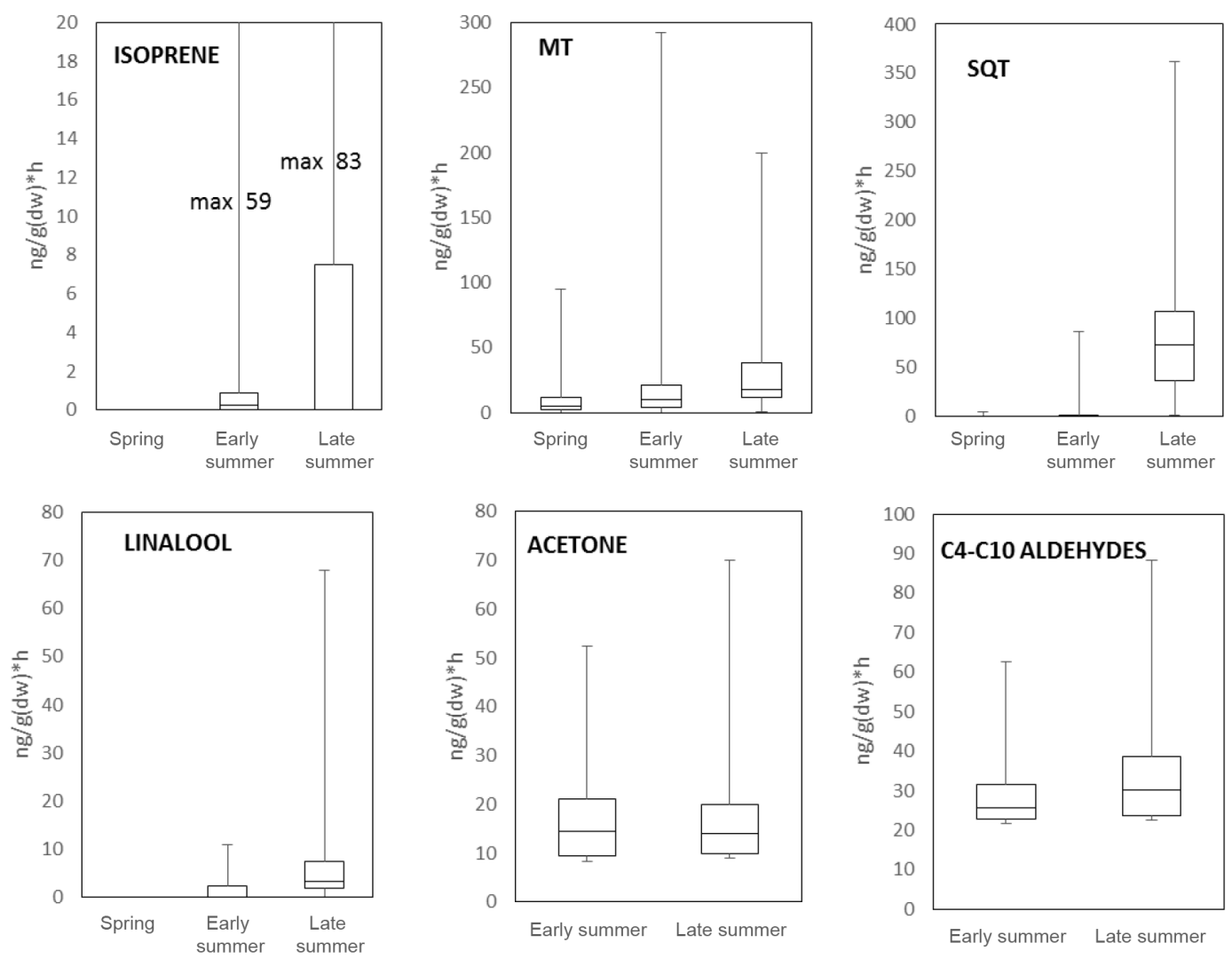

Figure 2. Season mean box and whisker plots of isoprene, MT, SQT, acetone, $\mathrm{C}_{4}-\mathrm{C}_{10}$ aldehydes (butanal, pentanal, hexanal, heptanal, octanal, nonanal, and decanal) and linalool. Boxes represent second and third quartiles and vertical lines in the boxes median values. Whiskers show the highest and the lowest observations.

emission rates were measured in late summer in the present study, Bourtsoukidis et al. (2014b) found highest emission rates in spring.

MT emission rates were below $50 \mathrm{ng} \mathrm{g}(\mathrm{dw})^{-1} \mathrm{~h}^{-1}$ most of the time in April and May, and still in the beginning of June for every measurement year, below $50 \mathrm{ng} g(\mathrm{dw})^{-1} \mathrm{~h}^{-1}$ most of the time. At the end of June the MT emission rates started to increase (about $30 \%$ ) to the level where they remained until the end of August, the daily maxima or their sum remaining below $300 \mathrm{ng}(\mathrm{dw})^{-1} \mathrm{~h}^{-1}$. In comparison with the study by Bourtsoukidis et al. (2014b), MT emission rates in Finland are four to ten times lower than those measured in Germany and their seasonal cycles are different. As with isoprene, they measured the highest MT emission rates during spring, whereas our highest emissions take place late summer. Median seasonal values reported by them are 203.1, 136.5, and $80.8 \mathrm{ng} \mathrm{g}(\mathrm{dw})^{-1} \mathrm{~h}^{-1}$ for spring, summer, and autumn, respectively. Our averages are 8,21 , and $28 \mathrm{ng} g(\mathrm{dw})^{-1} \mathrm{~h}^{-1}$ for spring, early summer, and late summer, respectively (Table 3 ).

A substantial change in the emission patterns took place at the end of July, when SQT emission rates increased up to 3-4 times higher than the MT emission rates at the same time (Table 3). Such a change in emissions was not observed in the study by Bourtsoukidis et al. (2014b). Instead of late summer increase, they again observed highest emissions during the spring (118.6 and $64.9 \mathrm{ng} \mathrm{g}(\mathrm{dw})^{-1} \mathrm{~h}^{-1}$ in spring and summer, respectively) after which emissions significantly declined. Moreover, they report that MTs dominated the Norway spruce emissions through the entire measuring period (April-November), SQT emission rates being equal to MT emission rates during spring, but only about half of MT emission rates during summer and about $20 \%$ during autumn. One potential explanation for such a different seasonality and emission strengths may lie in the differences between sitespecific factors such as soil moisture conditions, local climate (winter in Germany is much milder and the trees do not face as dramatic change as in Finland when winter turns to spring), stand age, or stress factors. The tree measured in Germany was much older (about 80 years). In a boreal forest, late summer normally is the warmest and most humid season favouring high emissions, as was also the case in our study periods. In contrast, in central Germany July was relatively cold and wet, and according to the authors, reduced emissions were therefore not surprising (Boutsourkidis et al., 2014b). 
Table 3. Seasonal mean emission rates of isoprene, 2-methylbutenol (MBO), MT, SQT, acetone, and $\mathrm{C}_{4}-\mathrm{C}_{10}$ carbonyls in ng $\mathrm{g}(\mathrm{dw})^{-1} \mathrm{~h}^{-1}$. "na" means that the compounds were not included in the analysis. Spring is April-May, early summer 1.6-15.7, and late summer 16.7-31.8. bdl: below detection limit. Values are averages and standard deviations for the three measurement years (2011, 2014, 2015). Other SQT: sum of all other SQTs in emissions. The number of the measurements each season is in parentheses.

\begin{tabular}{|c|c|c|c|c|c|c|}
\hline & \multicolumn{2}{|c|}{ Spring (337) } & \multicolumn{2}{|c|}{ Early summer (534) } & \multicolumn{2}{|c|}{ Late summer (159) } \\
\hline & average & SD & average & SD & average & $\mathrm{SD}$ \\
\hline Isoprene & & & 1.3 & 3.7 & 6.0 & 12 \\
\hline MBO & & & 2.1 & 4.2 & 2.4 & 3.8 \\
\hline Camphene & 1.1 & 1.8 & 2.9 & 4.4 & 3.8 & 4.1 \\
\hline 3-Carene & 0.3 & 0.7 & 1.1 & 1.7 & 0.9 & 0.6 \\
\hline$p$-Cymene & 0.3 & 0.6 & 0.9 & 1.8 & 0.5 & 0.5 \\
\hline Limonene & 2.7 & 3.4 & 6.1 & 12.2 & 7.7 & 9.5 \\
\hline Myrcene & 0.2 & 0.4 & 1.7 & 3.7 & 3.9 & 5.1 \\
\hline$\alpha$-Pinene & 2.1 & 3.4 & 5.8 & 11.1 & 9.6 & 11 \\
\hline$\beta$-Pinene & 1.0 & 2.2 & 1.8 & 6.2 & 0.9 & 1.1 \\
\hline Sabinene & 0 & 0.1 & 0.5 & 1.5 & 0.9 & 1.6 \\
\hline Terpinolene & 0 & 0.2 & 0.1 & 0.4 & 0.3 & 0.9 \\
\hline Bornylacetate & 0 & 0.2 & 0.5 & 2.0 & 1.1 & 2.1 \\
\hline 1,8-Cineol & 0.7 & 0.7 & 2.1 & 3.9 & 1.8 & 2.2 \\
\hline Linalool & na & & 1.4 & 2.2 & 7.9 & 12 \\
\hline$\beta$-Caryophyllene & 0 & 0 & 0.4 & 2.1 & 7.2 & 5.9 \\
\hline$\beta$-Farnesene & 0 & 0 & 1.1 & 4.3 & 42 & 29 \\
\hline Other SQT & 0.1 & 0.4 & 1.4 & 4.7 & 35 & 30 \\
\hline Acetone & na & & 17 & 11 & 17 & 9.0 \\
\hline Butanal & na & & 2.0 & 0.7 & 0.3 & 0.3 \\
\hline Pentanal & na & & 4.1 & 1.1 & 2.4 & 0.9 \\
\hline Hexanal & na & & 5.0 & 3.0 & 4.9 & 2.1 \\
\hline Heptanal & na & & 5.2 & 1.2 & 7.5 & 2.4 \\
\hline Octanal & na & & 0.3 & 0.1 & 0.4 & 1.1 \\
\hline Nonanal & na & & 6.3 & 2.3 & 9.9 & 4.5 \\
\hline Decanal & na & & 5.6 & 2.3 & 7.4 & 3.8 \\
\hline
\end{tabular}

Another interesting feature can be seen in the specified emission rates of different compounds. In the present study the main SQT in spruce emissions was $\beta$-farnesene. About $50 \%$ of the SQT emission consisted of $\beta$-farnesene and its maximum emission rate $\left(155 \mathrm{ng} g(\mathrm{dw})^{-1} \mathrm{~h}^{-1}\right)$ was measured on the afternoon of 31 July 2015 . Two other identified SQTs were $\beta$-caryophyllene and $\alpha$-humulene. There were two more SQTs, which also contributed significantly to the total SQT emission rates, but since no calibration standards were available for these, their quantification is only tentative. Linalool emissions increased simultaneously with SQT emissions (Fig. 2) reaching maximum concentrations during late summer in August, in the same way as was previously observed in the measurements of Scots pine emissions in the same forest in southern Finland (Hakola et al., 2006), where emissions were found to increase late summer concomitant with the maximum concentration of the airborne pathogen spores, and Hakola et al. (2006) suggested a potential defensive role of the conifer linalool and SQT emissions. Several other reports point to similar correlations between SQT (in particular $\beta$-farnesene) and oxygenated MTs such as linalool emissions and biotic stresses in controlled experiments. For example, increases in farnesene, methyl salicylate (MeSA), and linalool emissions were reported to be an induced response by Norway spruce seedlings to feeding damage by mite species (Kännaste et al., 2009), indicating that their biosynthesis might prevent the trees from being damaged. Interestingly, the release of $\beta$-farnesene seemed to be mite specific and attractive to pine weevils, whereas linalool and MeSA were deterrents. Blande et al. (2009) discovered pine weevil feeding to clearly induce the emission of MTs and SQTs, particularly linalool and (E) $\beta$-farnesene, from branch tips of Norway spruce seedlings, Also, in a licentiate thesis of Petterson (2007) linalool and $\beta$-farnesene were shown to be emitted due to stress. The emissions from Norway spruce increased significantly after trees were treated with methyl jasmonate (MeJA). Martin et al. (2003) discovered that MeJA triggered increases in the rate of linalool emission more than 100 -fold and that of SQTs more than 30-fold. Emissions followed a pronounced diurnal rhythm with the maximum amount released during the light period, suggesting that they are induced de novo after treatment. Our study shows that such major changes in emission patterns can also occur in trees in field conditions, and without any clear visible in- 

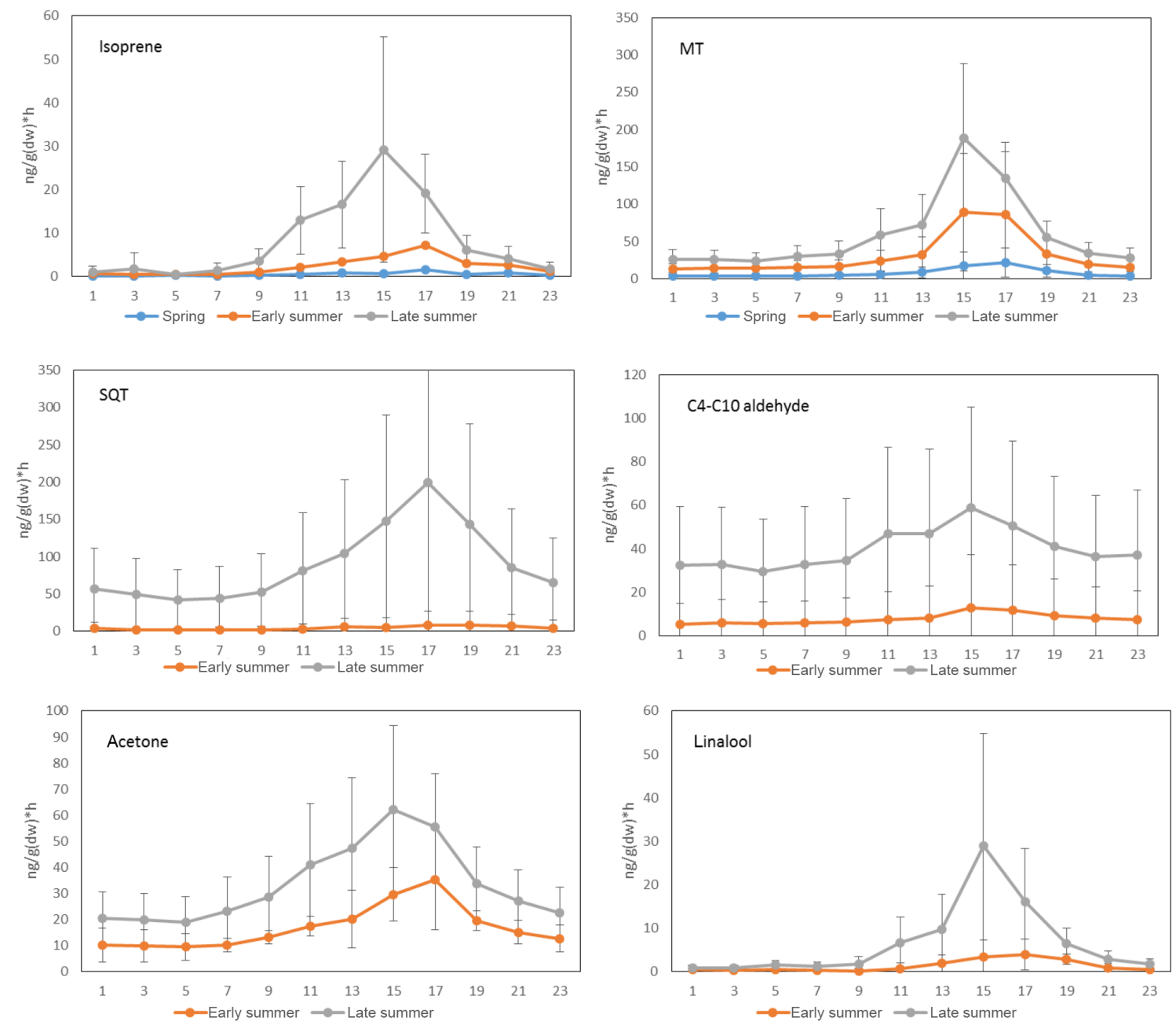

Figure 3. Mean diurnal variations of different compound groups in each season. Spring refers to April and May; early summer, June-midJuly; late summer, mid-July-August. Aldehydes are the sum of all $\mathrm{C}_{4}-\mathrm{C}_{10}$ aldehydes (butanal, pentanal, hexanal, heptanal, octanal, nonanal, and decanal).

festations or feeding, indicating that they probably are systemic defence mechanisms rather than direct ones (Eyles et al., 2010).

In 2015 we measured also acetone/propanal and $\mathrm{C}_{4}-\mathrm{C}_{10}$ aldehyde emission rates. The total amount of these measured carbonyl compounds was comparable to the amount of MTs (Table 3) although with our method it was not possible to measure emissions of the most volatile aldehydes, formaldehyde and acetaldehyde, which are also emitted from trees in significant quantities (Cojocariu et al., 2004; Koppmann and Wildt, 2007; Bourtsoukidis et al., 2014b). In summer 2015 the carbonyl compounds consisted mainly of acetone $(30 \%)$, and the shares for the other compounds were as follows: nonanal $(21 \%)$, decanal $(17 \%)$, heptanal (14\%), hexanal $(10 \%)$, and pentanal $(5 \%)$. The shares of butanal and octanal were less than $2 \%$ each. The seasonal mean values are shown in Table 3. Aldehydes with shorter carbon backbones (butanal, pentanal, hexanal) have higher emissions in early summer like most MTs, while aldehydes with longer carbon backbones (heptanal, octanal, nonanal, decanal) have higher emissions in late summer similarly to SQTs.

Diurnal variability of the emission rates of MT and SQT, acetone/propanal and larger aldehydes are shown in Fig. 2. They all show similar temperature-dependent variability with maxima during the afternoon and minima in the night. The SQT daily peak emissions were measured $2 \mathrm{~h}$ later than MT and aldehyde peaks.

\subsection{Tree-to-tree variability in emission pattern}

When following the emission seasonality, we discovered that the MT emission patterns were somewhat different between the two trees measured. The tree measured in 2011 (tree 1) emitted mainly $\alpha$-pinene in May, whereas the tree measured in 2014 and 2015 (tree 2) emitted mainly limonene in May (Table 4). As summer proceeded the contribution 
Table 4. Average monthly abundances (\%) of emitted MTs. T1 (tree 1) includes 2011 and T2 2014 and 2015 measurements. The number of the measurements each month is in parentheses.

\begin{tabular}{|c|c|c|c|c|c|c|c|c|c|}
\hline & $\alpha$-Pinene & Camphene & Sabinene & $\beta$-Pinene & Myrcene & $\Delta^{3}$-Carene & $p$-Cymene & Limonene & Terpinolene \\
\hline April, T1 (160) & 34 & 19 & 0 & 18 & 1 & 5 & 6 & 18 & 0 \\
\hline May, T1 (48) & 59 & 9 & 1 & 7 & 1 & 1 & 9 & 10 & 3 \\
\hline June, T1 (34) & 7 & 25 & 16 & 0 & 34 & 3 & 9 & 4 & 0 \\
\hline May, T2 (129) & 16 & 11 & 0 & 10 & 5 & 5 & 2 & 51 & 0 \\
\hline June, T2 (396) & 27 & 15 & 0 & 15 & 5 & 5 & 4 & 29 & 0 \\
\hline July, T2 (128) & 32 & 15 & 2 & 5 & 7 & 5 & 2 & 27 & 1 \\
\hline Aug, T2 (134) & 34 & 11 & 3 & 3 & 15 & 3 & 1 & 29 & 1 \\
\hline
\end{tabular}

of limonene emission decreased in both trees and the share of $\alpha$-pinene increased in tree 2 . The species-specific Norway spruce emissions have been measured earlier at least by Hakola et al. (2003) and Bourtsoukidis et al. (2014a). The measurements by Hakola et al. (2003) covered all seasons, but only a few daytime samples for each season, whereas the measurements by Bourtsoukidis et al. (2014a) covered 3 weeks in September-October in an Estonian forest. The main MTs detected in the Estonian forest were $\alpha$-pinene $(59 \%)$ and 3 -carene $(26 \%)$, but also camphene, limonene, $\beta$-pinene and $\beta$-phellandrene were detected. In the study by Hakola et al. (2003) the MT emission composed mainly of $\alpha$-pinene, $\beta$-pinene, camphene, and limonene, but only very small amounts of 3-carene were observed, similarly to the present study. This raises the question of whether spruces would have different chemotypes in a similar way as Scots pine has (Bäck et al., 2012).

In order to find out how much variability there was between the trees in monoterpene emission pattern, we conducted a study in June in 2014, where we made qualitative analysis from six different spruces growing in the same area (labelled as trees 3-8). The results for MT emissions are shown in Fig. 4. SQT emissions were not significant at that time (about $1 \mathrm{ng} g(\mathrm{dw})^{-1} \mathrm{~h}^{-1}$ ). As expected, the MT emission pattern of the trees was quite different; terpinolene was one of the main MT in the emission of four trees whereas tree 3 emitted only $3 \%$ terpinolene. Also limonene and camphene contributions were varying from a few percent to about a third of the total MT emission. All the measured trees emitted rather similar proportions of $\alpha$ - and $\beta$-pinene. The shares of myrcene, $\beta$-pinene, and 3-carene were low in every tree. Since different MTs react at different rates in the atmosphere (Table 1), the species-specific measurements are necessary when evaluating MTs influence on atmospheric chemistry. Currently, air chemistry models very often use only single branch measurements and this can lead to biased results when predicting product and new particle formation. This study and the study of Scots pine emissions by Bäck et al. (2012) show that species-specific measurements are necessary, but also that flux measurements are more representative than branch-scale emission measurements, and that av-

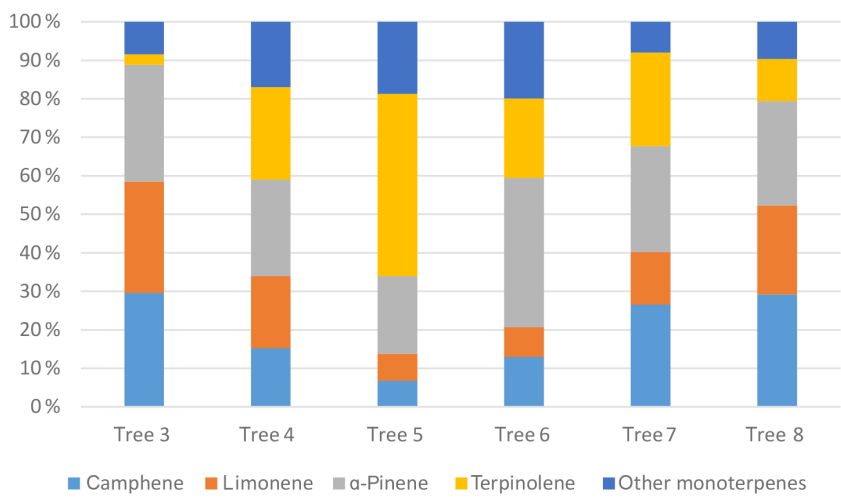

Figure 4. Relative abundances of emitted monoterpenes in six different spruce individuals on 24 June 2014.

eraging over larger spatial scale may be better suited for air chemistry models.

\subsection{Standard emission potentials}

The standard emission potentials were obtained by fitting the measured emission rates to the temperature-dependent pool emission algorithm (Eq. 2) and the light- and temperaturedependent algorithm described in Sect. 2.3. For the temperature dependent algorithm, the nonlinear regression was carried out with two fitted parameters, yielding both the emission potentials and individual $\beta$ coefficients for each compound group. With the light- and temperature-dependent algorithm, only emission potentials were obtained. The compounds' emissions fitted using the temperature-dependent pool emission algorithm were the ones of the most abundant MT and SQT, and the carbonyls for each season, while the analysis with the light- and temperature-dependent emission algorithm was carried out for isoprene emissions. In the analysis, obvious outliers and other suspicious data were not included. The excluded values typically were the first values obtained right after starting a measurement period, which might still show the effects of handling the sample branch. The isoprene emissions obtained in 2011 were not taken into account in the analysis as they were not properly collected on the cold trap. This was fixed in 2014 and 2015 by changing 
Table 5. Standard $\left(30^{\circ} \mathrm{C}\right) \mathrm{MT}$, SQT, acetone, and $\mathrm{C}_{4}-\mathrm{C}_{10}$ aldehyde emission potentials obtained in 2011 , 2014, and 2015 . For isoprene the standard $\left(1000 \mu \mathrm{mol}\right.$ photons $\left.\mathrm{m}^{-2} \mathrm{~s}^{-1}, 30^{\circ} \mathrm{C}\right)$ emission potentials are from the 2015 campaign. The standard emission potential $E_{\mathrm{S}}$ and the $\beta$ coefficient are given with the standard error of the estimate (SE, in parentheses). $R$ squared and the number of measurements ( $N$, in parentheses). The fits were made for the spring (April-May), early summer (June-mid-July) and late summer (late July-August) periods.

\begin{tabular}{|c|c|c|c|}
\hline Spring & Es $(\mathrm{SE}) \mathrm{ng} g(\mathrm{dw})^{-1} \mathrm{~h}^{-1}$ & $\beta \mathrm{K}^{-1}(\mathrm{SE})$ & $R^{2}(N)$ \\
\hline$\alpha$-Pinene & $11.6(0.7)$ & $0.097(0.006)$ & $0.423(331)$ \\
\hline Camphene & $2.5(0.4)$ & $0.045(0.009)$ & $0.071(323)$ \\
\hline$\beta$-Pinene & $1.9(0.2)$ & $0.044(0.007)$ & $0.119(324)$ \\
\hline Myrcene & $0.6(0.1)$ & $0.010(0.011)$ & $0.007(157)$ \\
\hline Limonene & $5.0(0.8)$ & $0.032(0.008)$ & $0.049(321)$ \\
\hline Other MT & $2.9(0.2)$ & $0.085(0.005)$ & $0.433(329)$ \\
\hline$\beta$-Caryophyllene & $0.2(0.1)$ & $0.018(0.059)$ & $0.026(6)$ \\
\hline$\beta$-Farnesene & - & - & $-(0)$ \\
\hline Other SQT & $0.7(0.3)$ & $0.046(0.029)$ & $0.029(72)$ \\
\hline \multicolumn{4}{|l|}{ Early summer } \\
\hline$\alpha$-Pinene & $14.1(1.0)$ & $0.058(0.006)$ & 0.145 (489) \\
\hline Camphene & $7.0(0.3)$ & $0.060(0.004)$ & $0.230(492)$ \\
\hline$\beta$-Pinene & $5.2(0.6)$ & $0.062(0.010)$ & $0.076(426)$ \\
\hline Myrcene & $5.8(0.3)$ & $0.078(0.005)$ & $0.326(356)$ \\
\hline Limonene & $16.7(0.9)$ & $0.069(0.005)$ & $0.239(497)$ \\
\hline Other MT & $7.0(0.3)$ & $0.074(0.004)$ & 0.385 (499) \\
\hline$\beta$-Caryophyllene & $4.8(1.3)$ & $0.018(0.019)$ & $0.023(54)$ \\
\hline$\beta$-Farnesene & $6.9(1.8)$ & $0.012(0.018)$ & $0.007(90)$ \\
\hline Other SQT & $6.2(0.7)$ & $0.055(0.010)$ & $0.087(238)$ \\
\hline Acetone & $50.8(7.2)$ & $0.066(0.010)$ & $0.362(71)$ \\
\hline Aldehydes & $59.1(4.4)$ & $0.043(0.005)$ & $0.503(71)$ \\
\hline \multicolumn{4}{|l|}{ Late summer } \\
\hline Isoprene & $56.5(4.2)$ & & $0.473(70)$ \\
\hline$\alpha$-Pinene & $39.3(4.1)$ & $0.153(0.017)$ & $0.359(163)$ \\
\hline Camphene & $7.7(1.2)$ & $0.064(0.016)$ & $0.094(161)$ \\
\hline$\beta$-Pinene & $2.5(0.3)$ & $0.075(0.015)$ & $0.160(120)$ \\
\hline Myrcene & $21.1(2.0)$ & $0.191(0.019)$ & $0.476(154)$ \\
\hline Limonene & $32.3(3.6)$ & $0.155(0.018)$ & $0.336(163)$ \\
\hline Other MT & $9.9(1.1)$ & $0.133(0.016)$ & $0.298(153)$ \\
\hline$\beta$-Caryophyllene & $11.0(1.2)$ & $0.020(0.010)$ & $0.032(129)$ \\
\hline$\beta$-Farnesene & $76.9(7.5)$ & $0.060(0.010)$ & $0.183(162)$ \\
\hline Other SQT & $67.3(8.2)$ & $0.059(0.013)$ & $0.132(157)$ \\
\hline Acetone & $31.8(2.2)$ & $0.061(0.007)$ & $0.313(163)$ \\
\hline Aldehydes & $36.8(3.0)$ & $0.008(0.007)$ & $0.009(163)$ \\
\hline
\end{tabular}

the adsorbent material. An approach with a hybrid algorithm, where the emission rate is described as a function of two source terms, de novo synthesis emissions and pool emissions, was also tested. However, the results were not conclusive.

The standard emission potentials of isoprene, the selected MT and SQT, acetone, and $\mathrm{C}_{4}-\mathrm{C}_{6}$ aldehyde sums are presented in Table 5. Emission potentials are given as spring, early summer, and late summer values. The coefficient of determination $\left(R^{2}\right)$ is also given, even though it is an inadequate measure for the goodness of fit in nonlinear models (e.g. Spiess and Neumeyer, 2010). A more reliable parame- ter for estimating the goodness of fit is the standard error of the estimate, which is also given.

The summertime emission potentials of MT and SQT reflect the typical behaviour of the temperature variability in summer, with low emissions in spring and high emissions in the higher temperatures of late summer. The variability of the emission potential during the growing season and between the individual compounds is large. In late summer limonene and $\alpha$-pinene had the highest MT emission potentials. SQT exhibit a similar behaviour as monoterpene emission potentials with very low springtime and early summer emission potentials while the late sum- 
mer emission potential is high. In a review by Kesselmeier and Staudt (1999) the reported standard emission potentials $\left(30^{\circ} \mathrm{C}, 1000 \mu \mathrm{mol} \mathrm{m}{ }^{-2} \mathrm{~s}^{-1}\right)$ of Norway spruces for monoterpenes vary from 0.2 to $7.8 \mu \mathrm{gg}$ (dry weight $)^{-1} \mathrm{~h}^{-1}$ and in a study by Bourtsoukidis et al. (2014b) mean emission potential of Norway spruce was $0.89 \mu \mathrm{gg}(\text { dry weight })^{-1} \mathrm{~h}^{-1}$ for all data (spring, summer, fall). Our standardized MT emission potentials are lower than earlier reported values, being $0.1 \mu \mathrm{gg}(\text { dry weight })^{-1} \mathrm{~h}^{-1}$ during late summer, when they were at their highest.

This is the first time we have applied fitting the traditional temperature-based emission potential algorithms to measured carbonyl emissions, and based on the spruce emission results, the approach appears to be applicable also on these compounds. The best fit was obtained with the temperaturedependent algorithm. The temporal variability of the emission potential was similar to MT- and SQTs. Unfortunately, acetone/propanal and $\mathrm{C}_{4}-\mathrm{C}_{10}$ aldehyde measurements were only carried out during the last measurement campaign, but the emission pattern possibly indicates a midsummer maximum, because emissions were clearly identified in June, and already decreasing in late July-August. The isoprene emissions, fitted with the light and temperature emission algorithm, also reflect the light/temperature pattern of summer, with low emissions in spring and high emissions in late summer.

In late summer when isoprene emissions were a bit higher the emission model fits the data better and the emission potential for isoprene was $56.5 \mathrm{ng} \mathrm{g}(\text { dry weight })^{-1} \mathrm{~h}^{-1}$. In a review by Kesselmeier and Staudt (1999) the reported standard emission potentials $\left(30^{\circ} \mathrm{C}, 1000 \mu \mathrm{mol} \mathrm{m} \mathrm{m}^{-2} \mathrm{~s}^{-1}\right)$ of isoprene vary from 0.34 to $1.8 \mu \mathrm{gg}$ (dry weight $)^{-1} \mathrm{~h}^{-1}$. Our standardized late summer mean $\left(56.5 \mathrm{ng} \mathrm{g}(\text { dry weight })^{-1} \mathrm{~h}^{-1}\right)$ is much lower than these earlier reported values.

\subsection{Relative reactivity of emissions}

In summer in ambient air at this site most of the known $\mathrm{OH}$ reactivity (which is $\sim 50 \%$ of the total measured $\mathrm{OH}$ reactivity) is coming from the VOCs (Sinha et al., 2010; Nölcher et al., 2012). Other trace gases $\left(\mathrm{NO}_{x}, \mathrm{CO}, \mathrm{O}_{3}, \mathrm{CH}_{4}\right)$ have a lower contribution. Of these VOCs, aromatic hydrocarbons have only minor contribution compared to the terpenoids (Hakola et al., 2012). In these ambient air studies contribution of SQTs has been much lower than MTs, but those results are misleading, since lifetimes of most SQTs are so short that they cannot be detected in ambient air and estimation of their contribution to the local reactivity is possible only directly from the emissions. Here we studied the relative role of different BVOCs to the reactivity of Norway spruce emissions.

The relative contribution from each class of compounds to the total calculated $\mathrm{OH}$ and $\mathrm{O}_{3}$ reactivity of the emissions TCRE $_{\mathrm{OH}}$ and $\mathrm{TCRE}_{\mathrm{O}_{3}}$, respectively, is depicted in Fig. 5. Nitrate radicals are likely to contribute also significantly to
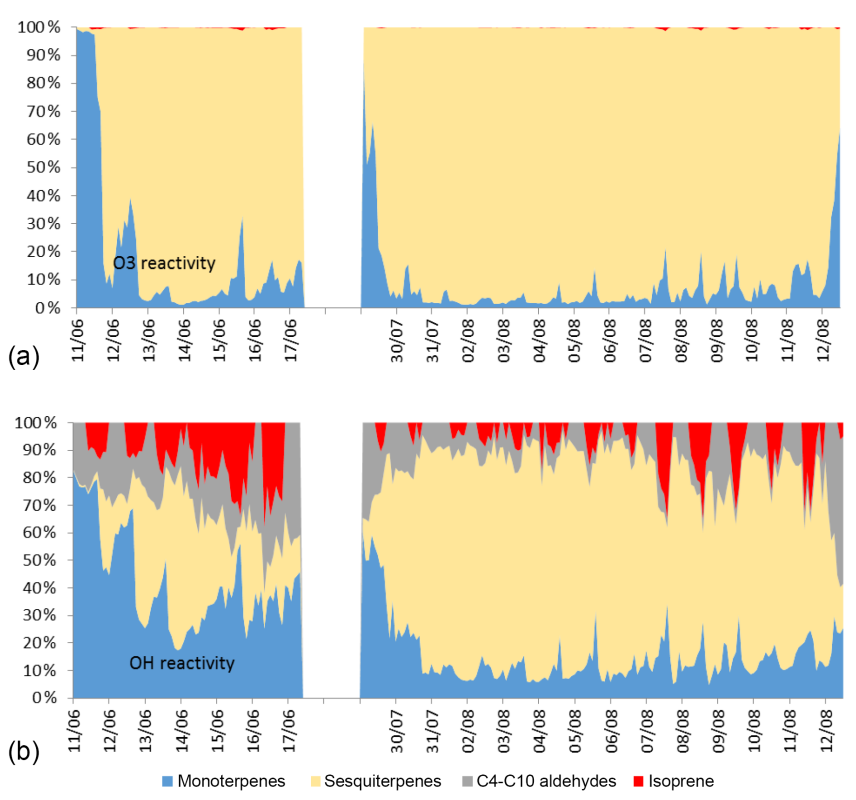

Figure 5. Relative $\mathrm{O}_{3}$ and $\mathrm{OH}$ reactivity of emissions for two periods in early and late summer 2015. The compounds and reaction coefficients used for reactivity calculations are presented in Table 1.

the reactivity, but since the reaction rate coefficients were not available for the essential compounds like $\beta$-farnesene, the nitrate radical reactivity is not shown. SQT are very reactive towards ozone and they clearly dominate the ozone reactivity. Isoprene contribution is insignificant all the time towards ozone reactivity, but it contributes $20-30 \%$ of $\mathrm{OH}$ reactivity, although the emission rates are quite low. SQT dominate also $\mathrm{OH}$ reactivity during late summer due to their high emission rates, but early summer MT contribution is equally important. Contribution of acetone to the TCRE $\mathrm{OH}$ was very small $(\sim 0.05 \%$ of total reactivity), but reactivity of $\mathrm{C}_{4}-\mathrm{C}_{10}$ aldehydes was significant, averagely $15 \%$ and sometimes over $50 \%$ of the TCRE $\mathrm{OH}_{\mathrm{H}}$. Of the aldehydes decanal, nonanal, and heptanal had the highest contributions. It is also possible to measure total $\mathrm{OH}$ reactivity directly and experimental total $\mathrm{OH}$ reactivity measurements by Nölscher et al. (2013) showed that the contribution of SQTs in Norway spruce emissions in Hyytiälä was very small $(\sim 1 \%)$. This is in contradiction to our measurements, where we found a very high share of SQTs ( $75 \%$ in late summer). Nölscher et al. (2013) also found a very high fraction of missing reactivity $(>80 \%)$ especially in late summer. Their measurements covered spring, summer, and autumn. Emissions of $\mathrm{C}_{4}-\mathrm{C}_{10}$ aldehydes, which were not studied by Nölscher et al. (2013), could explain part of the missing reactivity. 


\section{Conclusions}

Norway spruce VOC emissions were measured in campaigns in 2011, 2014 and 2015. Measurements covered altogether 14 spring and summer weeks. The measured compounds included isoprene, MT, and SQT and in 2015 also acetone and $\mathrm{C}_{4}-\mathrm{C}_{10}$ aldehydes. MT and SQT emission rates were low during spring and early summer. MT emission rates increased to their maximum at the end of June and declined a little in August. A significant change in SQT emissions took place at the end of July, when SQT emissions increased substantially. The seasonality is different from that observed earlier in Germany (Bourtsoukidis et al., 2014b). There Norway spruce emissions (isoprene, MT, SQT) were highest in spring and declined thereafter. The difference in seasonality can be due to different ages of the measured trees (10-15 years in the current study, 80 years in Bourtsoukidis et al., 2014b), different climate, or different stress factors. These same factors can also cause the lower emission rates measured now in comparison with other studies. The effect of age to the emission potentials should be studied.

In August SQT were the most abundant group in the emission, $\beta$-farnesene being the most dominant compound. SQT emissions increased simultaneously with linalool emissions and these emissions were suggested to be initiated due to stress effects. To our knowledge this is the first time when $\beta$-farnesene and linalool emissions have been shown to increase simultaneously in natural conditions, although they have been shown to increase in the emissions together due to stress effects. Of the measured compounds, SQTs had highest impact on local $\mathrm{O}_{3}$ and $\mathrm{OH}$ chemistry. This clearly shows the importance of considering also SQTs in atmospheric studies in boreal environment.

Acetone and $\mathrm{C}_{4}-\mathrm{C}_{10}$ aldehyde emissions were highest in July, when they were approximately at the same level as MT emissions. $\mathrm{C}_{4}-\mathrm{C}_{10}$ aldehydes contributed as much as MT to the $\mathrm{OH}$ reactivity during late summer, but early summer only about half of the MT share in early summer. This demonstrates that also emissions of other BVOCs than the traditionally measured terpenoids are important and should be included in atmospheric studies.

The MT emission pattern varies a lot from tree to tree. During one afternoon in June we measured the emission patterns of six different trees growing near each other and especially the amounts of terpinolene, camphene, and limonene were varying. Due to inconsistent emission patterns, speciesspecific emission fluxes at canopy level should be conducted in addition to the leaf level measurements for more representative measurements. However, only leaf-level measurements produce reliable SQT data.

Data availability. The data are available from the authors upon request.
Competing interests. The authors declare that they have no conflict of interest.

Acknowledgements. The financial support by the Academy of Finland Centre of Excellence programme (project no. 272041) and Academy Research Fellow programme (project no. 275608) are gratefully acknowledged. The authors thank Juho Aalto for determining the specific leaf area of the needles.

Edited by: A. Ding

Reviewed by: two anonymous referees

\section{References}

Aalto, J., Kolari, P., Hari, P., Kerminen, V.-M., Schiestl-Aalto, P., Aaltonen, H., Levula, J., Siivola, E., Kulmala, M., and Bäck, $\mathrm{J}$.: New foliage growth is a significant, unaccounted source for volatiles in boreal evergreen forests, Biogeosciences, 11, 13311344, doi:10.5194/bg-11-1331-2014, 2014.

Albaladejo, J., Ballesteros, B., Jiménez, E., Martín, P., and Martínez, E.: A PLP-LIF kinetic study of the atmospheric reactivity of a series of $\mathrm{C} 4-\mathrm{C} 7$ saturated and unsaturated aliphatic aldehydes with OH, Atmos. Environ., 36, 3231-3239, 2002.

Atkinson, R., Aschmann, S. M., and Arey, J.: Rate constants for the gas-phase reactions of $\mathrm{OH}$ and $\mathrm{NO}_{3}$ radicals and $\mathrm{O}_{3}$ with sabinene and camphene at $296 \pm 2 \mathrm{~K}$, Atmos. Environ., 24, 2647-2654, doi:10.1016/0960-1686(90)90144-C, 1990a.

Atkinson, R., Hasegawa, D., and Aschmann, S. M.: Rate constants for the gas-phase reactions of $\mathrm{O}_{3}$ with a series of monoterpenes and related compounds at $296 \pm 2 \mathrm{~K}$, Int. J. Chem. Kinet., 22, 871-887, doi:10.1002/kin.550220807, 1990b.

Atkinson, R., Arey, J., Aschmann, S. M., Corchnoy, S. B., and Shu, Y.: Rate constants for the gas-phase reactions of cis-3-Hexen-1ol, cis-3-Hexenylacetate, trans-2-Hexenal, and Linalool with $\mathrm{OH}$ and $\mathrm{NO}_{3}$ radicals and $\mathrm{O}_{3}$ at $296 \pm 2 \mathrm{~K}$, and $\mathrm{OH}$ radical formation yields from the $\mathrm{O}_{3}$ reactions, Int. J. Chem. Kinet., 27, 941-955, doi:10.1002/kin.550271002, 1995.

Atkinson, R. and Arey, J.: Atmospheric Degradation of Volatile Organic Compounds, Chem. Rev., 103, 4605-4638, doi:10.1021/cr0206420, 2003.

Atkinson, R., Baulch, D. L., Cox, R. A., Crowley, J. N., Hampson, R. F., Hynes, R. G., Jenkin, M. E., Rossi, M. J., Troe, J., and IUPAC Subcommittee: Evaluated kinetic and photochemical data for atmospheric chemistry: Volume II - gas phase reactions of organic species, Atmos. Chem. Phys., 6, 3625-4055, doi:10.5194/acp-6-3625-2006, 2006.

Bäck, J., Aalto, J., Henriksson, M., Hakola, H., He, Q., and Boy, M.: Chemodiversity of a Scots pine stand and implications for terpene air concentrations, Biogeosciences, 9, 689-702, doi:10.5194/bg-9-689-2012, 2012.

Blande, J. D., Turunen, K., and Holopainen, J. K.: Pine weevil feeding on Norway spruce bark has a stronger impact on needle VOC emissions than enhanced ultraviolet-B radiation, Environ. Pollut., 157, 174-180, 2009.

Bourtsoukidis, E., Bonn, B., Dittmann, A., Hakola, H., Hellén, H., and Jacobi, S.: Ozone stress as a driving force of sesquiter- 
pene emissions: a suggested parameterisation, Biogeosciences, 9, 4337-4352, doi:10.5194/bg-9-4337-2012, 2012.

Bourtsoukidis, E., Bonn, B., and Noe, S.: On-line field measurements of BVOC emissions from Norway spruce (Picea abies) at the hemiboreal SMEAR-Estonia site under autumn conditions, Boreal Environ. Res., 19, 153-167, 2014a.

Bourtsoukidis, E., Williams, J., Kesselmeier, J., Jacobi, S., and Bonn, B.: From emissions to ambient mixing ratios: online seasonal field measurements of volatile organic compounds over a Norway spruce-dominated forest in central Germany, Atmos. Chem. Phys., 14, 6495-6510, doi:10.5194/acp-14-6495-2014, 2014b.

Bourtsoukidis, E., Kawaletz, H., Radacki, D., Schutz, S., Hakola, H., Hellén, H., Noe, S., Molder, I., Ammer, C., and Bonn, B.: Impact of flooding and drought conditions on the emission of volatile organic compounds of Quercus robur and Prunus serotina, Trees, 28, 193-204, 2014c.

Bowman, J. H., Barket Jr., D. J., and Shepson, P. B.: Atmospheric Chemistry of Nonanal, Envir. Sci. Tech. Lib., 37, 2218-2225, doi:10.1021/es026220p, 2003.

Chameides, W. L., Fehsenfeld, F., Rodgers, M. O., Cardelino, C., Martinez, J., Parrish, D., Lonneman, W., Lawson, D. R., Rasmussen, R. A., Zimmerman, P., Greenberg, J., Middleton, P., and Wang, T.: Ozone precursor relationships in the ambient atmosphere, J. Geophys. Res., 97, 6037-6055, 1992.

Ciccioli, P., Brancaleoni, E., Frattoni, M., Di Palo, V., Valentini, R., Tirone, G., Seufert, G., Bertin, N., Hansen, U., Csiky, O., Lenz, R., and Sharma, M.: Emissions of reactive terpene compounds from orange orchards and their removal by within-canopy processes, J. Geophys. Res., 104, 8077-8094, 1999.

Coeur, C., Jacob, V., Foster, P., and Baussand, P.: Rate constant for the gas-phase reaction of hydroxyl radical with the natural hydrocarbon bornyl acetate, Int. J. Chem. Kinet., 30, 497-502, doi:10.1002/(SICI)1097-4601(1998)30:7<497::AIDKIN6>3.0.CO;2-N, 1998.

Cojocariu, C., Kreuzwieser, J., and Rennenberg, H.: Correlation of short-chained carbonyls emitted from Picea abies with physiological and environmental parameters, New Phytol., 162, 717727, doi:10.1111/j.1469-8137.2004.01061.x, 2004

Corchnoy, S. B. and Atkinson, R.: Kinetics of the gas-phase reactions of hydroxyl and nitrogen oxide $\left(\mathrm{NO}_{3}\right)$ radicals with 2carene, 1,8-cineole, p-cymene, and terpinolene, Envir. Sci. Tech. Lib., 24, 1497-1502, doi:10.1021/es00080a007, 1990.

Eyles, A., Bonello, P., Ganley, R., and Mohammed, C.: Induced resistance to pests and pathogens in trees, New Phytol., 185, 893908, doi:10.1111/j.1469-8137.2009.03127.x, 2010.

Fall, R.: Biogenic emissions of volatile organic compounds from higher plants, in: Reactive Hydrocarbons in the Atmosphere, edited by: Hewitt, C. N., San Diego, Academic Press, 43-96, 1999.

Ghirardo, A., Koch, K., Taipale, R., Zimmer, I., Schnitzler, J.-P., and Rinne, J.: Determination of de novo and pool emissions of terpenes from four common boreal/alpine trees by ${ }^{13} \mathrm{CO}_{2}$ labelling and PTR-MS analysis, Plant Cell Environ., 33, 781-792, 2010.

Gill, K. J. and Hites, R. A.: Rate Constants for the Gas-Phase Reactions of the Hydroxyl Radical with Isoprene, $\alpha$ - and $\beta$-Pinene, and Limonene as a Function of Temperature, J. Phys. Chem. A, 106, 2538-2544, doi:10.1021/jp013532q, 2002.
Grabmer, W., Kreuzwieser, J., Wisthaler, A., Cojocariu, C., Graus, M., Rennenberg, H., Steigner, D., Steinbrecher, R., and Hansel, A.: VOC emissions from Norway spruce (Picea abies L. [Karst]) twigs in the field - Results of a dynamic enclosure study, Atmos. Environ., 40, S128-S137, 2006.

Griffin, R. J., Cocker III, D. R., Flagan, R. C., and Seinfeld, J. H.: Organic aerosol formation from the oxidation of biogenic hydrocarbons, J. Geophys. Res., 104, 3555-3567, 1999.

Grosjean, E. and Grosjean, D.: Rate constants for the gasphase reaction of ozone with unsaturated oxygenates, Int. J. Chem. Kinet., 30, 21-29, doi:10.1002/(SICI)10974601(1998)30:1<21::AID-KIN3>3.0.CO;2-W, 1998.

Guenther, A. B., Zimmerman, P. R., Harley, P. C., Monson, R. K., and Fall, R.: Isoprene and monoterpene emission rate variability: Model evaluation and sensitivity analyses, J. Geophys. Res., 98, 12609-12627, 1993.

Guenther, A.: Seasonal and spatial variations in natural volatile organic compound emissions, Ecol. Appl., 7, 34-45, 1997.

Guenther, A. B., Jiang, X., Heald, C. L., Sakulyanontvittaya, T., Duhl, T., Emmons, L. K., and Wang, X.: The Model of Emissions of Gases and Aerosols from Nature version 2.1 (MEGAN2.1): an extended and updated framework for modeling biogenic emissions, Geosci. Model Dev., 5, 1471-1492, doi:10.5194/gmd-51471-2012, 2012.

Hakola, H., Rinne, J., and Laurila, T.: The hydrocarbon emission rates of Tea-Leaved Willow (Salix phylicifolia), Silver Birch (Betula pendula) and European Aspen (Populus tremula), Atmos. Environ., 32, 1825-1833, 1998.

Hakola, H., Laurila, T., Lindfors, V., Hellén, H., Gaman, A., and Rinne, J.: Variation of the VOC emission rates of birch species during the growing season, Boreal Environ. Res., 6, 237-249, 2001.

Hakola, H., Tarvainen, V., Laurila, T., Hiltunen, V., Hellén, H., and Keronen, P.: Seasonal variation of VOC concentrations above a boreal coniferous forest, Atmos. Environ., 37, 1623-1634, 2003.

Hakola, H., Tarvainen, V., Bäck, J., Ranta, H., Bonn, B., Rinne, J., and Kulmala, M.: Seasonal variation of mono- and sesquiterpene emission rates of Scots pine, Biogeosciences, 3, 93-101, doi:10.5194/bg-3-93-2006, 2006.

Hakola, H., Hellén, H., Hemmilä, M., Rinne, J., and Kulmala, M.: In situ measurements of volatile organic compounds in a boreal forest, Atmos. Chem. Phys., 12, 11665-11678, doi:10.5194/acp12-11665-2012, 2012.

Hansen, U. and Seufert, G.: Temperature and light dependence of $\beta$-caryophyllene emission rates, J. Geophys. Res., 108, 4801, doi:10.1029/2003JD003853, 2003.

Hari, P. and Kulmala, M.: Station for measuring ecosystematmosphere relations (SMEAR II), Boreal Env. Res., 10, 315322, 2005.

Hites, R. A. and Turner, A. M.: Rate constants for the gasphase $\beta$-myrcene $+\mathrm{OH}$ and isoprene $+\mathrm{OH}$ reactions as a function of temperature, Int. J. Chem. Kinet., 41, 407-413, doi:10.1002/kin.20413, 2009.

Holopainen, J. and Gershenzon, J.: Multiple stress factors and the emission of plant VOCs, Trends Plant Sci., 15, 176-184, 2010.

Jaoui, M., Kleindienst, T. E., Docherty, K. S., Lewandowski, M., and Offenberg, J. H.: Secondary organic aerosol formation from the oxidation of a series of sesquiterpenes: a-cedrene, b- 
caryophyllene, a-humuleneanda-farnesenewith $\mathrm{O}_{3}$, Hand $\mathrm{NO}_{3}$ radicals, Environ. Chem., 10, 178-193. 2013.

Jiménez, E., Lanza, B., Martínez, E., and Albaladejo, J.: Daytime tropospheric loss of hexanal and trans-2-hexenal: $\mathrm{OH}$ kinetics and UV photolysis, Atmos. Chem. Phys., 7, 1565-1574, doi:10.5194/acp-7-1565-2007, 2007.

Joutsensaari, J., Yli-Pirilä, P., Korhonen, H., Arola, A., Blande, J. D., Heijari, J., Kivimäenpää, M., Mikkonen, S., Hao, L., Miettinen, P., Lyytikäinen-Saarenmaa, P., Faiola, C. L., Laaksonen, A., and Holopainen, J. K.: Biotic stress accelerates formation of climate-relevant aerosols in boreal forests, Atmos. Chem. Phys., 15, 12139-12157, doi:10.5194/acp-15-12139-2015, 2015.

Kännaste, A., Vongvanich, N., and Borg-Karlson, A.-L.: Infestation by a Nalepella species induces emissions of $\mathrm{a}-$ and $\mathrm{b}$-farnesenes, (-)-linalool and aromatic compounds in Norway spruce clones of different susceptibility to the large pine weevil, Arthropod-Plant Inte., 2, 31-41, doi:10.1007/s11829-008-9029-4, 2008.

Kännaste, A., Nordenhem, H., Nordlander, G., and Borg-Karlson, A.-K.: Volatiles from a Mite-Infested Spruce Clone and Their Effects on Pine Weevil Behavior, J. Chem. Ecol., 35, 1262-1271, 2009.

Kesselmeier, J. and Staudt, M.: Biogenic volatile organic compounds (VOC): An overview on emission, physiology and ecology, J. Atmos. Chem., 33, 23-88, 1999.

Koppmann, R. and Wildt, J.: Oxygenated volatile organic compounds, in: Volatile organic compounds in the atmosphere, edited by: Koppmann, R., ISBN-13: 987-1-4051-3115-5, Blackwell Publishing, 129-173, 2007.

Kourtchev, I., Bejan, I., Sodeau, J. R., and Wenger, J. C.: Gas phase reaction of $\mathrm{OH}$ radicals with (E)- $\beta$-farnesene at $296 \pm 2 \mathrm{~K}$ : Rate coefficient and carbonyl products, Atmos. Environ., 46, 338-345, doi:10.1016/j.atmosenv.2011.09.061, 2012.

Loreto, F. and Schnitzler, J.-P.: Abiotic stresses and induced BVOCs, Trends Plant Sci., 15, 154-166, 2010.

Martin, D. M., Gershenzon, J., and Bohlmann, J.: Induction of Volatile Terpene Biosynthesis and Diurnal Emission by Methyl Jasmonate in foliage of Norway Spruce, Plant Physiol., 132, 1586-1599, 2003.

Niinemets, Ü.: Responses of forest trees to single and multiple environmental stresses from seedlings to mature plants: Past stress history, stress interactions, tolerance and acclimation, Forest Ecol. Manag., 260, 1623-1639, 2010.

Nölscher, A. C., Williams, J., Sinha, V., Custer, T., Song, W., Johnson, A. M., Axinte, R., Bozem, H., Fischer, H., Pouvesle, N., Phillips, G., Crowley, J. N., Rantala, P., Rinne, J., Kulmala, M., Gonzales, D., Valverde-Canossa, J., Vogel, A., Hoffmann, T., Ouwersloot, H. G., Vilà-Guerau de Arellano, J., and Lelieveld, J.: Summertime total $\mathrm{OH}$ reactivity measurements from boreal forest during HUMPPA-COPEC 2010, Atmos. Chem. Phys., 12, 8257-8270, doi:10.5194/acp-12-8257-2012, 2012.

Nölscher, A. C., Bourtsoukidis, E., Bonn, B., Kesselmeier, J., Lelieveld, J., and Williams, J.: Seasonal measurements of total $\mathrm{OH}$ reactivity emission rates from Norway spruce in 2011, Biogeosciences, 10, 4241-4257, doi:10.5194/bg-10-4241-2013, 2013.

Petterson, M.: Stress related emissions of Norway spruce plants, Licentiate thesis, KTH Royal Institute of Technology, Stockholm, ISBN-13: 978-91-7178-644-9, 2007.
Pinto-Zevallos, D., Hellén, H., Hakola, H., van Nouhuys, S., and Holopainen, J.: Herbivore-induced volatile organic compounds emitted by food plants of the Glanville Fritillary, Phytochem. Lett., 6, 653-656, 2013.

Rinne, J., Bäck, J., and Hakola, H.: Biogenic volatile organic compound emissions from Eurasian taiga: current knowledge and future directions, Boreal Env. Res., 14, 807-826, 2009.

Sanadze, G. A.: Biogenic isoprene (a review), Russ. J. Plant Physl.+, 51, 729-741, 2004.

Shu, Y. and Atkinson, R.: Atmospheric lifetimes and fates of a series of sesquiterpenes, J. Geophys. Res., 100, 7275-7281, doi:10.1029/95JD00368, 1995.

Sinha, V., Williams, J., Lelieveld, J., Ruuskanen, T., Kajos, M., Patokoski, J., Hellen, H., Hakola, H., Mogensen, D., Boy, M., Rinne, J., and Kulmala, M.: OH Reactivity Measurements within a Boreal Forest: Evidence for Unknown Reactive Emissions, Environ. Sci. Technol., 44, 6614-6620, doi:10.1021/es101780b, 2010

Spiess, A. and Neumeyer, N.: An evaluation of $R^{2}$ as an inadequate measure for nonlinear models in pharmacological and biochemical research: a Monte Carlo approach, BMC Pharmacology, 10, doi:10.1186/1471-2210-10-6, 2010.

Tarvainen, V., Hakola, H., Hellén, H., Bäck, J., Hari, P., and Kulmala, M.: Temperature and light dependence of the VOC emissions of Scots pine, Atmos. Chem. Phys., 5, 989-998, doi:10.5194/acp-5-989-2005, 2005.

Tarvainen, V., Hakola, H., Rinne, J., Hellén, H., and Haapanala, S.: Towards a comphrehensive emission inventory of terpenoids from boreal ecosystems, Tellus B, 59, 526-534, 2007.

Thévenet, R., Mellouki, A., and Le Bras, G.: Kinetics of $\mathrm{OH}$ and $\mathrm{Cl}$ reactions with a series of aldehydes, Int. J. Chem. Kinet., 32, 676-685, doi:10.1002/1097-4601(2000)32:11<676::AIDKIN3>3.0.CO;2-V, 2000.

Tunved, P., Hansson, H.-C., Kerminen, V.-M., Ström, J., Dal Maso, M., Lihavainen, H., Viisanen, Y., Aalto, P. P., Komppula, M., and Kulmala, M.: High natural aerosol loading over boreal forests, Science, 312, 261-263, 2006.

Vestenius, M., Hellén, H., Levula, J., Kuronen, P., Helminen, K. J., Nieminen, T., Kulmala, M., and Hakola, H.: Acidic reaction products of monoterpenes and sesquiterpenes in atmospheric fine particles in a boreal forest, Atmos. Chem. Phys., 14, 7883-7893, doi:10.5194/acp-14-7883-2014, 2014.

Vickers, C. E., Gershenzon, J., Lerdau, M. T., and Loreto, F.: A unified mechanism of action for volatile isoprenoids in plant abiotic stress, Nat. Chem. Biol., 5, 283-291, 2009.

Wildt, J., Kobel, K., Schuh-Thomas, G., and Heiden, A. C.: Emissions of oxygenated volatile organic compounds from plants, part II: Emissions of saturated aldehydes, J. Atmos. Chem., 45, 173196, 2003.

Yassaa, N., Song, W., Lelieveld, J., Vanhatalo, A., Bäck, J., and Williams, J.: Diel cycles of isoprenoids in the emissions of Norway spruce, four Scots pine chemotypes, and in Boreal forest ambient air during HUMPPA-COPEC-2010, Atmos. Chem. Phys., 12, 7215-7229, doi:10.5194/acp-12-7215-2012, 2012. 